\title{
THE INFLUENCE OF EMPLOYEE DEVELOPMENT AND EMPOWERMENT OF HUMAN RESOURCES TO THE PERFORMANCE OF PENITENTIARY ORGANIZATIONS IN GREATER BANDUNG
}

\author{
Lilis Yuaningsih \\ College of Administrative Study Bandung \\ isyeindiansera@yahoo.com
}

\begin{abstract}
The Low Performance of Penitentiary Organizations in Greater Bandung. The cause of the problem is allegedly Guidance for Employees and Empowerment of Human Resources has not been done on the Performance of Penitentiary Organizations in Greater Bandung. Human resources as part of the scope of Public Administration by using qualitative descriptive analysis research methods and quantitative analysis (path analysis), while the population is Bandung Correctional Institutions (Sukamiskin Class I Correctional Institution Bandung, Class IIA Banceuy Bandung and Class I Kebon Waru Bandung). Staff development and empowerment of human resources have been carried out in accordance with the capabilities of the apparatus at the Bandung Institute of Corrections. Simultaneously the effect of employee coaching and empowerment of human resources on the performance of the Bandung Correctional Institution in Greater Bandung was 69.9\%, while the epsilon was $30.1 \%$. Partial influence of employee coaching consisting of factors giving decent wages, providing opportunities and encouragement to develop careers, disciplining the rules to achieve high organizational effectiveness, The results of research indicate a new thing that Organizational Performance in Penitentiary in Greater Bandung needs make new breakthroughs so that employees can work more innovating into the future to produce employees who have high morale and fighting spirit in carrying out their duties. Meaning that it is necessary to optimize the development and empowerment of human resources towards the performance of organizations in Bandung Correctional Institutions in Greater Bandung.
\end{abstract}

Keyword: Influence, Performance, Organization

\section{Introduction}

The spirit of reform in particular regarding reforms Public administration has colored the empowerment of the state apparatus with the aim of realizing state administration that is able to support the smooth and integrated implementation of the tasks and functions of state government and development, by practicing the principles of good governance. A clean government capable of providing public goods and services, as expected by the community. The process of implementing state power in carrying out the provision of public goods and services is called governance, while the best practice is called good governance. For good governance to become a reality and be successful, it requires participation and commitment from all parties, in this case the government and the community. One of the efforts made for the realization of an organization that works effectively is by fostering employees and empowering human resources that are tough in anticipating all changes. Employee development refers to the process of providing motivation to subordinates in order to work optimally for the achievement of organizational goals efficiently and effectively. Human resources not only act as objects that must receive attention and protection and institutions, but also at the same time play a role as a subject that can determine the progress of the organization.

Thus the development of employees and the empowerment of human resources refers to the realization of good, effective and efficient government to support and fill the implementation of regional autonomy which is oriented to welfare, progress and quality excellence and integrated within the scope of the government sector (Public Sector), business entities (Private Sector) and social organization activities (Civil Society). In this connection, 
the main principles of Good Governance (B. Tjokroamidjojo,2001) :

1. Acountabilily.

2. Traspéraney.

3. Opens.

4. Rule of Law.

5. Falrnes, a Level Playing Fled.

Referring to the principles of Good Governance above, the public sector becomes an important part and needs to pay attention and implement the values of Good Governance as a form of organizational efforts oriented to success in the future through efforts to foster employees and empower human resources to accelerate the process of achieving performance, both individually and organizationally. The performance of the organization is referred to as completion of the work as a whole that has excellent quality standards, on time accompanied by an adequate amount of work in accordance with predetermined targets.

Associated with employee coaching that "Employee Development is quite significant influence on Employee Performance in the Field of Control and Development of the Regional Revenue Service of West Java Province". Meanwhile, related to the empowerment of human resources that "The effect of empowering human resources on employee performance at the Center for Increasing Water Resources Construction Engineering Expertise at the Department of Public Works in Bandung has a significant effect on Employee Performance".

Looking at the description above, it appears that employee development and empowerment of human resources quite significantly influence employee performance. Henceforth both of these variables need to be studied further in order to find out about the importance of employee coaching and human empowerment on other objects, including the Bandung Correctional Institutions consisting of Sukamiskin Class I Correctional Institutions, Class IIA Banceuy and Class I Kebon Waru. This research was conducted on the object of research in Greater Bandung Penitentiary which is a place to undergo criminal offenses for people who have been sentenced, for committing unlawful acts. Also as a place for fostering prisoners in the form of general and mental education and fostering independence by providing skills as a provision of life after being free and lawsuits.
The correctional process in its implementation is viewed from two aspects, namely security and coaching. Both must support one another, so that correctional institutions can carry out their functions effectively to realize the goals of the correctional system. The policy of guiding prisoners in correctional institutions consists of four stages, each of which contains the same goals and coaching process, with different levels of treatment according to the period of detention or criminal level. The coaching stages include: the maximum security stage. remedium security, medium security and minimum security (Sukmadinata, 2007).

Stages of maximum security, supervision of officers of prisoners is carried out strictly, because the coach does not yet know the nature, nature of prisoners' behavior. In addition, maintaining the security and influence of old inmates on new inmates. Supervision of this stage begins from the time a prisoner enters prison until $1 / 3$ of his sentence. In the remedium security stage, supervision by the supervisor is not as strict as in the agricultural stage. At this stage an evaluation of the implementation of the security program is carried out which determines whether a prisoner can proceed to the next stage or not. This stage is given since the prisoner has served $1 / 3$ to $1 / 2$ of his sentence. The medium security stage, oversight carried out on inmates is more lax than the previous stage. At this stage an evaluation of the security program continues, beginning with the prisoners serving a $1 / 2$ to $2 / 3$ criminal period. The minimum stage of security, supervision applied to prisoners is very loose. This stage is intended for prisoners who have served $2 / 3$ of their criminal sentences.

Sukamiskin Penitentiary, Banceuy and Kebon Waru are correctional facilities located in the Greater Bandung area. These three institutions are tasked with carrying out guidance for prisoners to increase guidance for prisoners. Article I Paragraph (1) Government Regulation Number 31 of 1999 states that what is meant by guidance is to increase devotion to God Almighty, Intellectual, Professional Attitudes and Behavior, Physical and Spiritual Health of prisoners and students of the community. (BPHN, Based on these regulations, the Implementation of guidance policies in prison include personality development and self-help development so that the guidance process is undertaken by fostered citizens since entering prison as convicts and completing their sentences or prison terms. The success of 
fostering prisoners in prison is determined by the ability of all prison security officers especially those relating to the development of employees and the empowerment of human resources to improve overall organizational performance. In reality, prison staff have difficulty in developing employee or staff development and human resource empowerment, so that the overall performance of these penitentiary organizations is weak.

Table 1. Recapitulation of the performance of prison organizations in Bandung

\begin{tabular}{|c|c|c|c|}
\hline Numb. & Class 1 Sukamiskin & Class 2A Banceuy & Class 1 Kebon Waru \\
\hline 1. & $\begin{array}{l}\text { completed the } 2009- \\
2010 \text { annual report } \\
\text { from } 25 \text { reports only } \\
\text { completed } 20 \text { reports. }\end{array}$ & $\begin{array}{l}\text { the preparation of } \\
\text { the } 2009-2010 \\
\text { annual report from } \\
22 \text { reports only } \\
\text { completed } 18 \\
\text { reports. }\end{array}$ & $\begin{array}{l}\text { the preparation of the prisoner training } \\
\text { program agenda for } 2009-2010 \text { out of } \\
16 \text { programs only implemented } 12 \\
\text { programs. }\end{array}$ \\
\hline 2. & $\begin{array}{l}\text { inmates' training was } \\
\text { unsuccessful because } \\
5 \text { prisoners in 2009- } \\
2010 \text { escaped. }\end{array}$ & $\begin{array}{l}\text { inmate training is } \\
\text { handled } \\
\text { unprofessionally } \\
\text { and supervision is } \\
\text { weak. }\end{array}$ & $\begin{array}{l}\text { development services for prisoners are } \\
\text { provided only on physical skills. }\end{array}$ \\
\hline
\end{tabular}

Based on the results of preliminary research in the Bandung Correctional Institution Class I Sukamiskin Class II, Class IIA Banceuy and Class I Kebon Waru allegedly the organizational performance of the prison organization was low. This is based on the following problem indicators:

1. The work productivity of Penal Institutions is low. For example: in Lapas KIas I Banceuy, the results of work related to the preparation of guidance and supervision reports, prison staff are less able to take the initiative to compile complete data, so that the evaluation draft that is made does not contain information relating to guidance and supervision, it should be reported 3 months once to the Regional Office of the Ministry of Law and Human Rights, in fact the report is carried out every 5 months.

2. The quality of correctional services (prisons) is low. For example: in Sukamiskin Class IIA Prison there are still many officers who carry out their duties without professional skills, this is allegedly there are still recidivists who have fled and Sukamiskin Prison which causes unrest in the community. Penitentiary Public Responsibility (Lapas) is low. For example: in Kebon Waru Class I Detention Center the preparation of service agendas and priorities as well as the development of public service programs are not in accordance with the rules that lead to the low formation of prisoners, thereby inciting fights between prisoners.
Based on the indicators of the problem, it is suspected that the problem is not yet carried out coaching employees and optimal development of human resources. Furthermore, to look at the problem in more depth, the researcher is interested in conducting research within the scope of employee development and empowerment of human resources and employee performance by formulating the title: "The Effect of Employee Development and Human Resource Empowerment on Organizational Performance in Bandung Raya Correctional Institutions (Research at the Sukamiskin Class I Penitentiary, Class IIA Banceuy and Class I Kebon Waru). Interesting to study because so far it has been very exclusive, and (3) This institution needs to be studied more deeply about the behavior of prison officials in carrying out the guidance and supervision of prisoners in these institutions. The reason for its location in Greater Bandung, given the Correctional Institutions in West Java is quite a lot, almost every District and City there is a Penitentiary.

Based on the background above, the problem statement in this study, namely the performance of the Bandung Correctional Institution in Bandung Raya is low. This was alleged by the lack of Employee Development and Empowerment of Human Resources on the Performance of Penitentiary Organizations (Lapas) in Greater Bandung. And the statement of the problem and the cause of the problem, can be identified research questions (Problem Question) as follows:

1. How is the Implementation of Employee Development and Empowerment of Human Resources in Improving the 
Performance of Penitentiary Organizations (Lapas) in Greater Bandung.

2. How much influence the Employee Development and Human Resources Empowerment on the Performance of Penitentiary Organizations in Greater Bandung.

3. How much influence Employee Development through factors: Giving a decent salary; Providing opportunities and encouragement to develop a career; Discipline of rules to achieve high organizational effectiveness; Providing adequate rest; Giving awards for services or services to the organization both material and immaterial; Providing opportunity to gather in employee organizations; Provision of fair work and social facilities; Safety, security and occupational health; Providing stimulants; Provision of recreational arrangements and provision of old age pension or retirement for the Performance of Penitentiary Organizations in Greater Bandung.

4. How much influence the empowerment of human resources through principles: develop a shared vision; educating, removing obstacles; revealed; encouraging; equip; assess and expect principles on the performance of Penitentiary Organizations throughout Greater Bandung.

\section{Method}

The framework of thinking that will be outlined in this section focuses on determining the objectives and direction of research and to select references that are relevant and specific to the problem to be examined. In this context, researchers will try to compile concepts from existing theories as a basis for thinking to explain the structure of the relationship between the factors involved in the correlation between the issues of Employee Development and Empowerment of Human Resources and Organizational Performance.

Employee Development is actually one of the core and management, therefore empirically Employee Development has a very sirategis position in carrying out the activities of an organization. In this context, an understanding of the level of Employee Development seems to be a necessity so that the implementation of its activities can be carried out in accordance with the objectives of the organization, that employee coaching in Indonesia aims to: Increase the ability of people to compete in the increasingly rapid development of the world. Nurturing Indonesian people in order to maintain themselves as people who have strong personalities that are related to the development of nationalism and spiritual attitudes that strengthen feelings of piety to God Almighty. (Suprayogi, 2011). Based on the description above, related to the general and specific goals of Employee Development has shown that Employee Development is a variable that is considered potential for optimizing employee career development. The development of employees is more aimed at increasing the ability and personality of each employee in carrying out their duties and functions. With regard to employee coaching above Clutterbuck and Kernaghan translations state the important factors of employee coaching as follows (Clutterbuce, 2003) :

Providing decent salaries / wages.

1. Providing opportunities and encouragement to develop a career.

2. Discipline the rules for achieving high organizational effectiveness.

3. Providing adequate rest.

4. Giving awards for services or dedication to the organization both material and immaterial

5. Providing opportunity to gather in employee organizations.

6. Providing equitable work and social facilities

7. Safety, security and occupational health.

8. Giving stimulants.

9. Providing or arranging recreation.

10. Provision of old age pension or retirement.

Observing the above view, it appears that there are important factors that are part and development of employees starting from the provision of adequate salary / wages to the provision of old age pension or pension. In reality it is not enough that the eleven factors above guarantee the success of the organization, because many other factors provide support for the achievement of organizational goals, including the need for empowerment of human resources. According to Carver in Clutterbuck and Kernaghan states 
that: Empowerment as an effort to encourage and enable individuals to assume personal responsibility for their efforts to improve the way they do their jobs and contribute to the achievement of organizational goals (Clutterbuce, 2003).

More clearly about the empowerment of human resources researchers will put forward the notion of empowerment put forward by Rivai, interpreting that empowerment as follows: Empowerment is a process of teaching and learning that is a planned and systematic effort that is carried out continuously, both for individuals and collectives for the development of power (potential) and the abilities contained in individuals and organizations so as to be able to carry out social transformation (Muladi, 1995). Empowerment is an effort to encourage and give each person personal responsibility to do his job and give something to the organization. This requires that a product of culture which both drives people at every level can change (make a difference) and encourage the confidence and expertise to do anything.

After explaining the thought framework of Employee Development and Organizational Performance variables, the relationship between the two variables is then stated. Mangkunegara stated that "Employee Development is a structured and scheduled activity for improving employee performance". Thus, it appears that coaching employees as activities that have a structure and time that has been determined in such a way. (Veithzal, 2009). In accordance with the above description, then to look at the relationship of the three variables above, Clutterbuck and Kernaghan stated that: "The development of J3 employees is individualistic which must be followed up with the empowerment of human resources which are institutional in nature, so as to improve individual or organizational performance". It appears that employee coaching is an individual skill, to complete the success and development of employees, it needs to be followed up with overall organizational empowerment of human resources. (Monang, 2009)

Based on the identification of the problem and frame of mind above, the authors propose the following hypothesis: a. If the Implementation of Employee Development and Human Resource Empowerment is carried out optimally, the Organizational Performance at Bandung Correctional Institutions increases.

b. Employee Development and Empowerment of Human Resources has a great influence on Organizational Performance in Bandung Correctional Institutions.

c. Employee Development through: Factors for the provision of decent salary / wages; Providing opportunities and encouragement to develop a career; Discipline of rules to achieve high organizational effectiveness; Providing adequate rest; Giving awards for services or services to the organization both material and immaterial; Providing opportunity to gather in employee organizations; Providing fair work and social facilities; Safety, security and occupational health; Providing stimulants; Provision or arrangement of recreation and Provision of collateral for old age or retirement greatly affect the Organizational Performance of Penitentiary in Greater Bandung.

d. Empowering Human Resources through: Principles Developing a shared vision; Educate; Remove obstacles; Revealed; Encouraging; Complete; Assess and Principles Expect a great influence on Organizational Performance in Bandung Correctional Institutions.

The research method used is the explanatory survey method, which is a method that aims to test the research hypotheses that have been formulated previously. According to Arikunto (2009) that to analyze the data used descriptive statistical techniques that function to group data, work on, conclude, explain and present the processed results. It aims to make the pattern of relationships or causes of aldbat between the value of a variable (dependent variable) if the other values are related to it (independent variable). This research uses quantitative analysis, intended to test Ian hypotheses and to interpret data in depth.

\section{Research Variables}

This research was conducted using two research variables, therefore the relationship form is only based on two variables, namely the independent variable (the independent variable) and the dependent variable (the 
dependent variable depends). The two research variables are independent variables: Employee Development and Human Resources Empowerment and the dependent variable: Organizational Performance.

2. Research Population
The population in this study is the Bandung Raya Penitentiary (Lapas) consisting of Sukamiskin Prison, Banceuy and Kebon Waru with members of the population structural officials in the penitentiary, each of which has duties and responsibilities according to the rules. Furthermore the number of respondents can be seen as follows:

Table 2. Respondent population

\begin{tabular}{clc}
\multicolumn{1}{c}{$\mathbf{N = 6 6}$} & \\
\hline Numb. & \multicolumn{1}{c}{ Work Units } & Amount \\
\hline 1. & $\begin{array}{l}\text { Sukamiskin } \\
\text { prison structural } \\
\text { officer }\end{array}$ & 29 \\
\hline 2. & $\begin{array}{l}\text { Banceuy prison } \\
\text { structural officer }\end{array}$ & 19 \\
\hline 3. & $\begin{array}{l}\text { Kebon Waru } \\
\text { prison structural } \\
\text { officer }\end{array}$ & 22 \\
\hline \multicolumn{2}{c}{ Total Amount } & 70 \\
\hline
\end{tabular}

3. Data Collection Technique

Data collection techniques used in carrying out this research are as follows:

a. Literature study, which is a study by studying books or other written materials that are related to the research conducted.

b. Field studies, i.e. data collection studies that go directly into the field in the following ways:

1) Observation, i.e. data collection is carried out through field observations of Sukamiskin Lapas, Banceuy and Kebon Waru Structural Officers.
2) Interview, which is collecting data by holding oral questions and answers directly to the Head of Sukamiskin Prison, Banceuy and Kebon Waru.

3) Questionnaire, namely by distributing a list of questions that are closed, where each question has available 5 alternative answers that are considered in accordance with practical reality. Answer categories and respondents weighting criteria for the contents of the questionnaire are presented below:

Table 3. Statement Value

\begin{tabular}{|c|l|c|c|}
\hline \multirow{2}{*}{ Numb. } & \multicolumn{1}{|c|}{ Statement } & \multicolumn{2}{|c|}{ Score } \\
\cline { 3 - 4 } & & Positive & Negative \\
\hline 1. & Very Agree & 5 & 1 \\
\hline 2. & Agree & 4 & 2 \\
\hline 3. & Neutral & 3 & 3 \\
\hline 4. & Disagree & 2 & 4 \\
\hline 5. & Very Disagree & 1 & 5 \\
\hline
\end{tabular}

4. Data Analysis Technique

Data analysis was performed through statistical tests, after the data were collected through a research questionnaire. Data testing is performed using path analysis, which is to measure the direct and indirect effects and independent variables on the dependent variable. Analysis of the data used in the tabulation guidelines data with the following standards: a. Minimum Index Value, which is the minimum score multiplied by the number of statements multiplied by the number of respondents.

b. Maximum Index Value, which is the maximum score multiplied by the number of statements times the number of respondents.

c. Level Range, namely the desired Range level for the given category consists of 
and levels: very low, medium, high and very high. Range, is the difference between the maximum index value minus the minimum index value.

Before the questionnaire is used for data collection, the validity of Construc Validity and reliability is tested through the Internal Consistency-test. Operationally the validity test is done by correlating the score for each item with the total score through the Person correlation formula as follows:

$$
r_{y x}=\frac{N \sum x y-\sum x \sum y}{\sqrt{\left[N \sum X^{2}\left(\sum x\right)^{2} I N \sum Y^{2}-\left(\sum y\right)^{2}\right]}}
$$

Information:

$r$ : The coefficient of validity sought.

$X$ : The score obtained by subjects in each item.

$\mathrm{Y}$ : Scores obtained by subjects and all items.

$\mathrm{N}$ : Total Subjects.

According to Masrun in Sugiyono (2010), if the correlation score $(r)>0.3$, then the item is valid. Furthermore, according to the hypothesis proposed by the path diagram as follows:

\section{Result and Discussion}

After knowing the results of the research through statistical analysis, the next description will be carried out the stages of discussion both descriptively, simultaneously and partially and the variables of employee coaching and empowerment of human resources on organizational performance. Discussion in descriptive as well as the influence of the two independent variables on the dependent variable, will be discussed in accordance with the theory put forward by experts. The employee coaching variable will discuss employee coaching factors from Clutterbuck and Kerhaghan (Monang, 2009) while the human resource empowerment variable will discuss the principles of empowering human resources and Stewart in Hardjana (1998: 112). As stated in the theoretical framework in Chapter II above. (Yuliawantini, 2013)

\section{Descriptive Discussion of the Implementation of Employee Development and Human Resource Empowerment in Organization Performance of Greater Bandung Correctional Institutions.}

Descriptively from the results of the research analysis it has been found that the

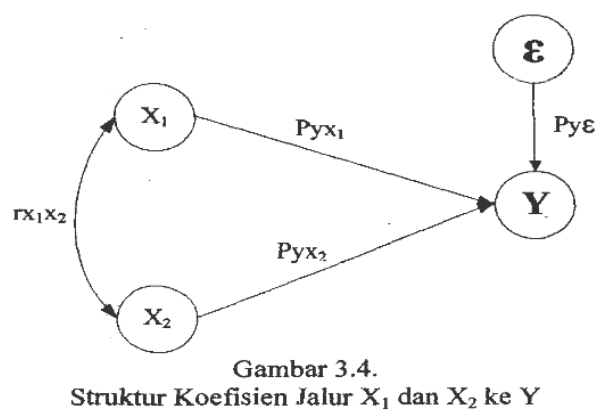

Information:

$\mathrm{X} 1$ : Employee Development

X2: Empowerment of Human Resources

rx: Correlation Coefficient.

Pyx: The effect of $x$ on $y$

Pya: Residual path coefficient to y

Pyx1 = Employee Development influences the Performance of Organizations in Bandung Correctional Institutions.

Pyx2 = Empowerment of Human Resources influences Organizational Performance in Bandung Correctional Institutions.

implementation of employee development and empowerment of human resources has been carried out in accordance with the capabilities of the public apparatus at the Correctional Institution, both at Sukamiskin Class I Correctional Institution, Bandung, Class IIA Banceuy Bandung and Class I Kebon Waru Bandung. However, when viewed from the results of research through the factors of employee coaching and the principles of empowerment of human resources, it turns out that each of the factors of employee coaching and the principles of empowering human resources has not fully shown positive results. Employee coaching factors from Clutterbuck and Kernaghan in Hidayat (2003: 47) (KBBI, 2001) and the principles of human resource empowerment from Stewart in Hardjana (1998: 112) Yuliawantini, 2013) cannot be fully implemented, so the research findings are sufficient varied and very interesting to study in this discussion descriptively.

Based on the findings of the implementation of employee coaching and empowerment of human resources on organizational performance in Bandung Raya Correctional Institution shows significant results, meaning these results show positive results where both independent variables are quite significant for 
improving organizational organization Penitentiary in Greater Bandung.

\section{Discussion on the Effect of Employee Development and Human Resource Empowerment on the Organization Performance of Greater Bandung Correctional Institutions.}

Having known the results of the research both the direct and indirect influence of employee development variables and the empowerment of human resources on the performance of penitentiary organizations in Greater Bandung, then the effects of the two independent variables on the dependent variable will be discussed next. The results showed that the direct effect of employee coaching on the performance of Penitentiary organizations in Greater Bandung was 52.2\%. The magnitude of this value indicates that the variable of employee coaching has a significant effect on the performance of prison organizations in Greater Bandung. As it is known that employee coaching is one of the important variables and administration and management, therefore empirically coaching employees has a strategic position in carrying out the activities of an organization that must be carried out seriously.

The success of employee coaching is in accordance with Syaifullah's opinion which states regarding the purpose of employee coaching aimed at:

a. Increasing the ability of people to compete in an increasingly rapid world development.

b. Nurturing Indonesian people so that they remain firm as people with strong personalities.

c. Strengthening national and physical attitude that is accompanied by religious submission to the Almighty God.

Understanding of the goals of the development of employees is clearly seen that the development of employees is intended to optimize the ability of employees in carrying out their duties. In addition, it is intended to develop the career of employees who are equipped with the ability to adapt to the environment that has a strong personality in facing various challenges and demands of society, especially in correctional institutions.

\author{
Discussion on the Effect of Employee \\ Development on Organizational \\ Performance of Greater Bandung \\ Correctional Institutions
}

The results showed that the influence of Employee Development on Organizational Performance in Bandung Raya Correctional Institution directly had a significant effect, with a value of $52.2 \%$, meaning that all Employee Coaching activities had been running optimally in accordance with the tasks and responsibilities that have been determined by the organization and prescribed rules. The effort of coaching employees by the leadership of correctional institutions is theoretically not easy to do, because coaching of employees as human beings must be carried out with a long process through in-depth recognition of the characteristics possessed by everyone, so as to be able to develop capabilities optimally. The employee coaching process needs to be carried out in stages and hierarchical tiered and starting from the initial stage, to the final stage. After recognizing the characteristics of employees, then they are measured in terms of the skills and competencies concerned so that they can be placed at a level or line of position in accordance with their abilities.

Furthermore, it is known that the employee's coaching must be carried out through clear stages, so that Clutterback and Kernaghan in Hidayat [5] stated 11 (eleven) important factors that need to be considered for employee coaching. This is in accordance with the discussion on the framework of thought that is the theoretical reference in this study. Employee coaching will also determine the back and forth of the organization, where the employee shelter and devote themselves to providing services to prisoners. However, it is not enough to provide guidance to these employees without having professional skills and abilities that are supported by the provision of appropriate rewards in accordance with their positions and positions.

Discussion on the Effect of Empowerment of Human Resources on the Performance of Penitentiary Organizations in Greater Bandung

The results showed that the effect of Empowerment of Human Resources on 
Organization Performance of Bandung Raya Correctional Institution was not directly significant, with a value of $17.7 \%$, meaning that activities related to empowering human resources had not been carried out optimally by the leadership. Efforts to empower human resources by the leader theoretically need to be done in stages, because the empowerment of human resources as an important part of determining the creation of employees who have the ability and expertise in accordance with their duties and responsibilities. Empowerment of human resources is a grouping of employees who are empowered to occupy positions and positions in accordance with the expertise of employees by first knowing their education, experience and expertise so that placement in positions does not experience significant obstacles. The principles of empowering human resources are examined through the opinion of Stewart in Hardjana (Yuliawantini, 2013). As discussed in the framework of thought that is the reference theory in this research.

\section{Other Influences (epsilon)}

Based on the results of the study there are differences between the results of research that are simultaneous and partial beikaitan with external influences. Simultaneously the magnitude of the value of external influences is $30.1 \%$. While partially the influence of the magnitude of epsilon's contribution to factors of coaching employees $4.3 \%$, the figure shows that there are other factors that influence, meaning that these factors provide meaning for improving overall Organizational Performance. While the amount of epsilon's contribution to the principles of empowering human resources is $0.9 \%$, meaning that the principle gives meaning to Organizational Performance that needs to be considered for the improvement of Overall Organizational Performance. The percentage difference, both simultaneously and partially is intended to ensure that the institution's leadership pays serious attention to carrying out its duties. There is a difference in the meaning of the amount of value between the factors of employee coaching and the principles of empowering human resources on organizational performance, the meaning of the difference is qualitatively the need to pay attention to these two differences significantly and pay attention to improve them seriously and conduct further research.

\section{Conclusion}

Based on the results of research on the influence of Employee Development and Human Resource Empowerment on Organizational Performance of Penitentiary Institutions in Greater Bandung, as stated in the description of the results of research and discussion, then it can conclusively summarize the results of the research as follows:

1. Implementation of Employee Development and Empowerment of Human Resources on Organizational Performance of Bandung Raya Correctional Institutions has been carried out in accordance with the capabilities of the public apparatus at Sukamiskin Class I Correctional Institution Bandung, Class IIA Penitentiary Institution, Banceuy Bandung and Klas I Kebon Waru State Prison Bandung. However, when viewed from the results of research through the factors of employee coaching and the principles of empowerment of human resources, each factor of employee coaching and the principles of empowerment of human resources showed varied results. Nevertheless the results of the study as a whole showed positive results, meaning that the two independent variables were quite significant for improving the organization of Penitentiary in Bandung Raya.

2. The simultaneous influence of Employee Development and Human Resources Empowerment on Organizational Performance shows significant results. Although the influence of Employee Coaching shows high results, it means that the employee coaching variable is quite dominant, in this case the leadership of the institution has carried out the task of coaching employees in accordance with their duties and obligations as the leader of the correctional institution seriously. Meanwhile the influence of Human Resources Empowerment results of the study showed small results, meaning that the variable of human resource empowerment was less dominant, in this case the leadership of the institution did not need to carry out empowerment of human resources 
attentively to create employees who worked full of dedication.

3. Partial influence of employee coaching consisting and factors of giving a proper salary, providing opportunities and encouragement to develop a career, disciplining rules to achieve high organizational effectiveness, providing adequate rest, giving appreciation for services or services to the organization both material and immaterial, providing opportunities for associations in employee organizations, providing work and social facilities that are just, safety and security as well as occupational health, incentives, giving or arranging recreation, and providing retirement or pension benefits affect Organizational Performance at Bandung Correctional Institutions in Greater Bandung. In this context the disciplinary factors to the rules for achieving high organizational effectiveness, have the highest influence.

4. The partial effect of empowering human resources consisting of the principles of educating, removing obstacles, revealing, encouraging, equipping, assessing and expecting to have an influence on the Organization Performance of Penitentiary Institutions in Bandung Raya. In this context the principle of encouraging gives the highest influence. While the principle of equipping provides the lowest influence on organizational performance. The results of the study show that there are new things that employees can work professionally to create more advanced and developing correctional institutions.

5. The results of this study also found that Employee Development and Human Resource Empowerment in Organization Performance in Bandung Raya Correctional Institution were not only influenced by the factors and principles of the two independent variables, but there were other influential factors and principles to be carried out.

\section{References}

Arikunto, S.(2009). Prosedur Penelitian Suatu Pendekatan Praktek. Jakarta: Rineka Cipta
B. Tjokroamidjojo. (2001). Reformasi Administrasi Administrasi Publik, vii. Jakarta: Universitas Krisnadwipayana.

BPHN. (1999). Peraturan Pernerintah Nomor 31 Tahun 1999 tentang pembinaan dan pembimbingan warga binaan Pemasyarakatan. Jakarta: BPHN.go.id.

Cholid, N \& Abu Achmadi. (2001). Metodologi Penelitian. Jakarta: Bumi Aksara.

Dadang, K. (2000). Metode Penelitian Agama. Bandung : CV Pustaka Setia.

Dwidja, P. (2009). Sistem Pelaksanaan Pidana Penjara Di Indonesia Cet Kedua, PT. Refika Aditama.

H. Veithzal Rivai. (2009). Islamic human capital : dari teori ke praktik manajemen sumber daya Islami. Jakarta: Rajawali Press.

Harsono. (1995). Sistem Baru Pembinaan Narapidana. Jakarta : Djambatan, Jakarta.

J. Supranto. (2003). Metode Penelitian Hukum dan Statistik. Jakarta : PT Rineka Cipta.

KBBI. (2001). Kamus Besar Bahasa Indonesia. Cetakan Ketiga. Jakarta : Balai Pustaka.

Monang, S. (2009). Pengaruh Pemberdayaan dan Pengawasan terhadap Kualitas Pelayanan Perijinan SIUP Pada Dinas Perindustrian dan Perdagangan Kota Medan,"VISI, vol. 17, no. 1, p. 23.

Muladi. (1995). Lembaga Pemasyarakatan dalam Perspektif Sistem Peradilan Pidana. Jakarta: Pustaka Sinar Harapan,

S. Clutterbuck, David, Kernaghan. (2003). The Art of HRD The Power of Empowerment: Daya Pemberdayaan Menggali dan Meningkatkan Potensi Karyawan Anda. Yogyakarta: Gramedia Pustaka Utama, 2003.

Sugiyono. (2011). Metode penelitian pendidikan (pendekatan kuwantitatif,kuwalitatif, $R \& D)$ ). Bandung: Alfabeta

Sukmadinata, N. S. (2007). Landasan Psikologi Proses Pendidikan. Bandung: Remaja Rosdakarya. 
Suprayogi, Y. (2011). Trasformasi Administrasi negara: persfektif Manajerial, Pertama. Bandung: falsafa,

Yuliawantini, I. (2013). Analisis Pengaruh Pemberdayaan Sumber Daya Manusia terhadap Kinerja Pegawai di Bagian Humas Pada Biro Humas, Protokol dan Umum Sekretariat Daerah Provinsi Jawa, Barat. bab II,Universitas Pasundan.

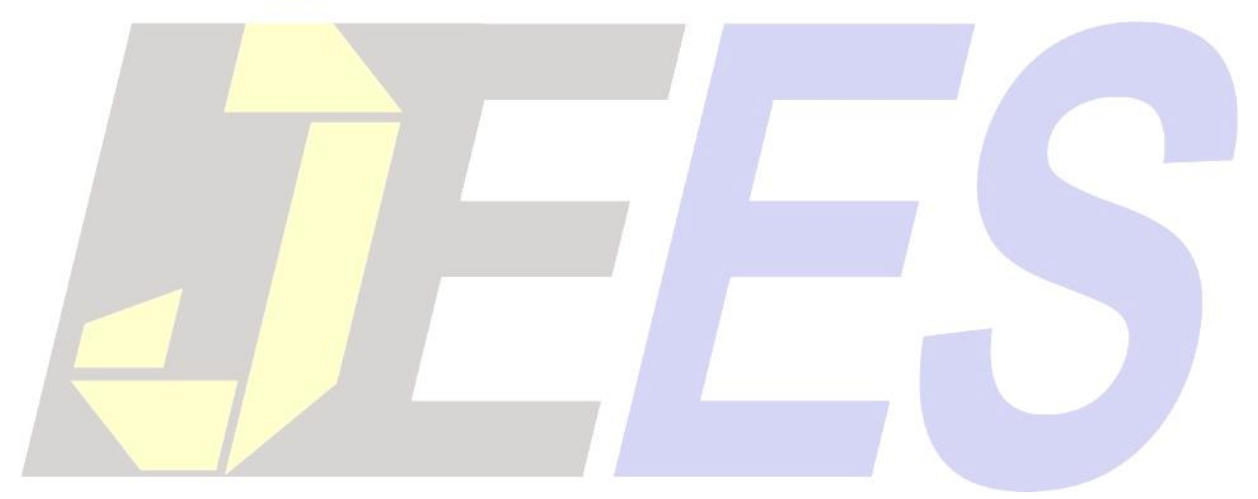

